\title{
Fungal Phytase Production in Different Hosts: A Brief Review
}

Godoi RR¹, Andrade SFV11, Machado JM¹, de Souza TPP1, Gonçalves AFA', Lopes TB1 ${ }^{1}$, Parachin $\mathrm{NS}^{2}$, Naves $\mathrm{LP}^{3}$, Lima $\mathrm{WJN}^{4}$, Pereira VV1 and Galdino $\mathrm{AS}^{1^{*}}$

${ }^{1}$ Microbial Biotechnology Laboratory, Universidade Federal de São João Del-Rei, Brazil

2Molecular Biology Laboratory, Universidade de Brasília, Brazil

${ }^{3}$ Food Analyses Laboratory, Universidade José do Rosário Vellano, Brazil

${ }^{4}$ Biotechnology Laboratory, Universidade Federal de Minas Gerais, Brazil

*Corresponding author: Alexsandro S Galdino, Microbial Biotechnology Laboratory, Universidade Federal de São João Del-Rei, Divinópolis, MG, Brazil 35501-2296, Tel: +55 (37) 3250-5494; E-mail: asgaldino@ufsj.edu.br

\section{Review Article \\ Volume 2 Issue 2}

Received Date: May 12, 2017

Published Date: June 15, 2017

DOI: $10.23880 /$ oajmb-16000120

\section{Abstract}

In this mini review we describe the main results of biotechnology studies on fungal phytases available in the literature, their main host cells and mutagenicity methodologies in order to expand our knowledge on fungal phytases produced in different host systems.

Keywords: Phytase; Filamentous Fungi; Heterologous expression

\section{Introduction}

The phytate (phytic acid) present in plants, especially in cereals, is an anti-nutrient that chelates metals and reduces its absorption during digestion in monogastric animals. Excretion of undigested phytate can cause serious ecological problems due to phosphorus excess. Phytases are acid phytic-degrading enzymes used in animal feed supplementation. The great majority of phytases used in animal feed are from fungal origin due to important biochemical properties of these enzymes, such as: thermostability at high temperatures, optimal activity in acidic conditions, and resistance to proteolysis of stomach enzymes such as pepsin and trypsin (Table 1). Taken together, these characteristics in a unique enzyme make these proteins as an important input in industrial animal feed. The main goal of this review article was describe the main hosts used (Figure 1) for expression of recombinant fungal phytases, their advantages and the tools currently used, to generate new phytases with potent industrial properties.

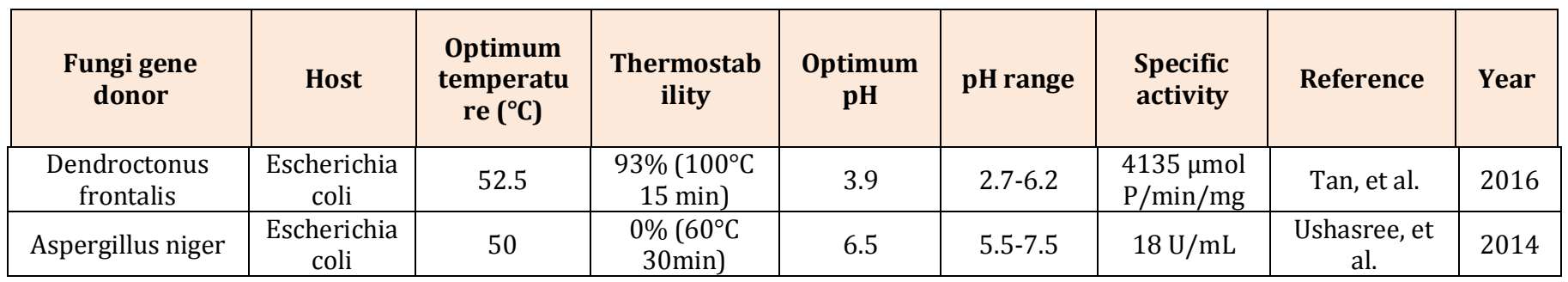


Open Access Journal of Microbiology \& Biotechnology

\begin{tabular}{|c|c|c|c|c|c|c|c|c|}
\hline $\begin{array}{c}\text { Aspergillus niger } \\
113\end{array}$ & $\begin{array}{l}\text { Escherichia } \\
\text { coli }\end{array}$ & 60 & $\begin{array}{c}20 \%\left(80^{\circ} \mathrm{C}\right. \\
8 \mathrm{~min})\end{array}$ & 2.0 and 5.0 & $1.5-6.0$ & $28.1 \mathrm{U} / \mathrm{mg}$ & Tian, et al. & 2011 \\
\hline Aspergillus niger & $\begin{array}{l}\text { Pichiapasto } \\
\text { ris }\end{array}$ & 60 & $\begin{array}{c}80 \%\left(80^{\circ} \mathrm{C}\right. \\
30 \mathrm{~min})\end{array}$ & 5.5 & - & $\begin{array}{c}148 \\
\mu \mathrm{M} / \mathrm{min} / \mathrm{m} \\
\mathrm{g}\end{array}$ & $\begin{array}{l}\text { Hesampour, } \\
\text { et al. }\end{array}$ & 2015 \\
\hline $\begin{array}{c}\text { Aspergillus } \\
\text { japonicus C03 }\end{array}$ & $\begin{array}{l}\text { Pichiapasto } \\
\text { ris }\end{array}$ & 50 & $\begin{array}{c}50 \%\left(80^{\circ} \mathrm{C} 7\right. \\
\min )\end{array}$ & $3.5,6.0,7.5$ & $3.0-8.0$ & $526 \mathrm{U} / \mathrm{mg}$ & $\begin{array}{l}\text { Maldonado, } \\
\text { et al. }\end{array}$ & 2014 \\
\hline $\begin{array}{c}\text { Aspergillus niger } \\
\text { N25 } \\
\end{array}$ & $\begin{array}{c}\text { Pichiapasto } \\
\text { ris }\end{array}$ & 55 & $\begin{array}{c}80 \%\left(80^{\circ} \mathrm{C}\right. \\
10 \mathrm{~min})\end{array}$ & 2.5 and 5.0 & $2.5-6.5$ & 985 U/mg & Liao, et al. & 2013 \\
\hline $\begin{array}{c}\text { Aspergillus niger } \\
\text { N25 } \\
\end{array}$ & $\begin{array}{c}\text { Pichiapasto } \\
\text { ris }\end{array}$ & 55 & - & 5.5 & $2.5-6.5$ & 204 U/mg & Liao, et al. & 2012 \\
\hline $\begin{array}{c}\text { Aspergillus niger } \\
\text { N25 } \\
\end{array}$ & $\begin{array}{c}\text { Pichiapasto } \\
\text { ris }\end{array}$ & 55 & - & 5.5 & $3.5-5.5$ & 330 U/mg & Liao, et al. & 2012 \\
\hline Penicillium sp. & $\begin{array}{l}\text { Pichiapasto } \\
\text { ris 002-28 }\end{array}$ & 55 & $\begin{array}{c}72.81 \% \\
\left(100^{\circ} \mathrm{C} 5 \mathrm{~min}\right) \\
\end{array}$ & 6 & $3.0-7.5$ & $133.3 \mathrm{U} / \mathrm{mg}$ & Zhao, et al. & 2010 \\
\hline Penicillium sp. & $\begin{array}{l}\text { Pichiapasto } \\
\text { ris 2-249 }\end{array}$ & 50 & $\begin{array}{c}92.43 \% \\
\left(100^{\circ} \mathrm{C} 5 \mathrm{~min}\right)\end{array}$ & 4.8 & $2.5-7.0$ & $136.6 \mathrm{U} / \mathrm{mg}$ & Zhao, et al. & 2010 \\
\hline $\begin{array}{c}\text { Aspergillus niger } \\
\mathrm{N}-3\end{array}$ & $\begin{array}{l}\text { Pichiapasto } \\
\text { ris }\end{array}$ & 55 & $\begin{array}{c}45 \%\left(90^{\circ} \mathrm{C} 5\right. \\
\min )\end{array}$ & 2.0 and 5.5 & $1.5-7.5$ & $495 \mathrm{U} / \mathrm{mL}$ & Shi, et al. & 2009 \\
\hline $\begin{array}{c}\text { Aspergillus } \\
\text { fumigatus WY-2 } \\
\end{array}$ & $\begin{array}{c}\text { Pichiapasto } \\
\text { ris }\end{array}$ & 55 & $\begin{array}{c}43.7 \%\left(90^{\circ} \mathrm{C}\right. \\
15 \mathrm{~min}) \\
\end{array}$ & 5.5 & $2.5-7.0$ & $51 \mathrm{U} / \mathrm{mg}$ & Wang, et al. & 2007 \\
\hline Peniophoralycii & $\begin{array}{c}\text { Pichiapasto } \\
\text { ris }\end{array}$ & 50 & $\begin{array}{c}25 \%\left(80^{\circ} \mathrm{C}\right. \\
10 \mathrm{~min})\end{array}$ & 4.5 & $2.5-7.5$ & $\begin{array}{l}10540 \\
\mathrm{U} / \mathrm{mL}\end{array}$ & Xiong, et al. & 2006 \\
\hline $\begin{array}{c}\text { Aspergillus } \\
\text { fumigatus }\end{array}$ & $\begin{array}{l}\text { Pichiapasto } \\
\text { ris }\end{array}$ & 60 & $\begin{array}{c}8 \%\left(70^{\circ} \mathrm{C}\right. \\
2 \mathrm{~min})\end{array}$ & 5 & $3.0-7.0$ & $\begin{array}{c}3300 \\
\eta \text { Kat } / \mathrm{mg}\end{array}$ & Ullah, et al. & 2000 \\
\hline Aspergillus niger & $\begin{array}{l}\text { Pichiapasto } \\
\text { ris }\end{array}$ & 60 & $\begin{array}{c}45 \%\left(80^{\circ} \mathrm{C}\right. \\
15 \mathrm{~min})\end{array}$ & 2.5 and 5.5 & $2.0-7.0$ & $64 \mathrm{U} / \mathrm{mL}$ & Han and Lei & 1999 \\
\hline $\begin{array}{l}\text { Aspergillus niger } \\
\text { NRRL } 3135\end{array}$ & $\begin{array}{l}\text { Saccharom } \\
\text { yces } \\
\text { cerevisiae }\end{array}$ & - & 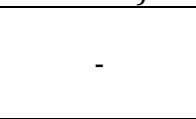 & 3.0 and 6.0 & $2.0-6.0$ & - & $\begin{array}{l}\text { Mullaney, et } \\
\text { al. }\end{array}$ & 2002 \\
\hline Aspergillus niger & $\begin{array}{l}\text { Saccharom } \\
\text { yces } \\
\text { cerevisiae }\end{array}$ & $55-60$ & $\begin{array}{c}75 \%\left(80^{\circ} \mathrm{C}\right. \\
15 \mathrm{~min})\end{array}$ & $\begin{array}{c}2 \text { to } 2.5 \\
\text { and } 5 \text { to } \\
5.5\end{array}$ & $2.0-6.0$ & $2797 \mathrm{U} / \mathrm{L}$ & $\begin{array}{l}\text { Yanming,et } \\
\text { al. }\end{array}$ & 1999 \\
\hline $\begin{array}{l}\text { Aspergillus } \\
\text { nigerCB }\end{array}$ & $\begin{array}{l}\text { Saccharom } \\
\text { yces } \\
\text { cerevisiae }\end{array}$ & 59 & $\begin{array}{l}48 \%\left(60^{\circ} \mathrm{C}\right. \\
20 \mathrm{~min})\end{array}$ & - & - & - & Wyss, et al. & 1999 \\
\hline $\begin{array}{l}\text { Aspergillus } \\
\text { terreus9A1 }\end{array}$ & $\begin{array}{l}\text { Saccharom } \\
\text { yces } \\
\text { cerevisiae }\end{array}$ & - & - & - & - & - & Wyss, et al. & 1999 \\
\hline $\begin{array}{l}\text { Aspergillus } \\
\text { fumigatus }\end{array}$ & $\begin{array}{l}\text { Saccharom } \\
\text { yces } \\
\text { cerevisiae }\end{array}$ & 55 & $\begin{array}{c}27 \%\left(60^{\circ} \mathrm{C}\right. \\
20 \mathrm{~min})\end{array}$ & - & - & - & Wyss, et al. & 1999 \\
\hline $\begin{array}{l}\text { Aspergillus } \\
\text { ficuum }\end{array}$ & $\begin{array}{l}\text { Aspergillus } \\
\text { niger }\end{array}$ & 58 & $\begin{array}{c}40 \%\left(70^{\circ} \mathrm{C}\right. \\
10 \mathrm{~min})\end{array}$ & 2.5 and 5.5 & $4.0-7.0$ & $\begin{array}{c}3000 \\
\text { nKat/mg }\end{array}$ & $\begin{array}{l}\text { Ullah and } \\
\text { Sethumadha } \\
\text { van }\end{array}$ & 2003 \\
\hline Aspergillusficuum & $\begin{array}{l}\text { Aspergillus } \\
\text { niger }\end{array}$ & 58 & $\begin{array}{c}40 \%\left(70^{\circ} \mathrm{C}\right. \\
10 \mathrm{~min})\end{array}$ & 2.5 and 5.5 & $2.0-7.0$ & $\begin{array}{c}3600 \\
\text { nKat/mg }\end{array}$ & $\begin{array}{l}\text { Ullah and } \\
\text { Sethumadha } \\
\text { van }\end{array}$ & 2003 \\
\hline $\begin{array}{l}\text { Aspergillus } \\
\text { terreus }\end{array}$ & $\begin{array}{c}\text { Aspergillus } \\
\text { nigerNW } \\
205 \\
\end{array}$ & 30 & $\begin{array}{c}18 \%\left(55^{\circ} \mathrm{C}\right. \\
20 \mathrm{~min})\end{array}$ & 4.5 & - & $160 \mathrm{U}$ & $\begin{array}{l}\text { Jermutus, et } \\
\text { al. }\end{array}$ & 2001 \\
\hline $\begin{array}{l}\text { Aspergillus } \\
\text { fumigatus }\end{array}$ & $\begin{array}{l}\text { Aspergillus } \\
\text { nigerNW20 } \\
5\end{array}$ & 55 & $\begin{array}{c}25 \%\left(60^{\circ} \mathrm{C}\right. \\
20 \mathrm{~min})\end{array}$ & - & - & - & Wyss, et al. & 1999 \\
\hline $\begin{array}{l}\text { Emericella } \\
\text { nidulans }\end{array}$ & $\begin{array}{c}\text { Aspergillus } \\
\text { nigerNW20 } \\
5\end{array}$ & - & - & - & - & - & Wyss, et al. & 1999 \\
\hline Myceliophthora & Aspergillus & - & - & - & - & - & Wyss, et al. & 1999 \\
\hline
\end{tabular}




\section{Open Access Journal of Microbiology \& Biotechnology}

\begin{tabular}{|c|c|c|c|c|c|c|c|c|}
\hline thermophila & $\begin{array}{c}\text { nigerNW20 } \\
5 \\
\end{array}$ & & & & & & & \\
\hline $\begin{array}{l}\text { Aspergillus } \\
\text { nigerCB }\end{array}$ & $\begin{array}{c}\text { Aspergillus } \\
\text { nigerNW20 } \\
5 \\
\end{array}$ & 59 & $\begin{array}{c}57 \%\left(60^{\circ} \mathrm{C}\right. \\
20 \mathrm{~min})\end{array}$ & - & - & - & Wyss, et al. & 1999 \\
\hline $\begin{array}{l}\text { Aspergillus } \\
\text { terreus9A1 }\end{array}$ & $\begin{array}{c}\text { Aspergillus } \\
\text { nigerNW20 } \\
5 \\
\end{array}$ & - & - & - & - & - & Wyss, et al. & 1999 \\
\hline $\begin{array}{l}\text { Aspergillus } \\
\text { fumigatus }\end{array}$ & $\begin{array}{l}\text { Aspergillus } \\
\text { niger }\end{array}$ & - & $\begin{array}{c}90 \%\left(100^{\circ} \mathrm{C}\right. \\
20 \mathrm{~min})\end{array}$ & 3.0 and 5.0 & $2.0-6.5$ & $350 \mathrm{U} / \mathrm{ml}$ & $\begin{array}{l}\text { Pasamontes, } \\
\text { et al. }\end{array}$ & 1997 \\
\hline $\begin{array}{c}\text { Aspergillus } \\
\text { nigerNRRL3 } 135\end{array}$ & $\begin{array}{l}\text { Aspergillus } \\
\text { niger }\end{array}$ & - & - & - & - & - & $\begin{array}{l}\text { Hartingsveldt } \\
\text {, et al. }\end{array}$ & 1993 \\
\hline Aspergillusoryzae & $\begin{array}{l}\text { Aspergillus } \\
\text { oryzae } \\
\text { RIB40 } \\
\end{array}$ & 37 & - & 5.5 & - & $\begin{array}{c}2.0 \mathrm{U} / \mathrm{mL} \\
\text { ou } 38.3 \\
\mathrm{U} / \mathrm{mg} \\
\end{array}$ & Uchida, et al. & 2006 \\
\hline Peniophoralycii & $\begin{array}{l}\text { Aspergillus } \\
\text { oryzae }\end{array}$ & 58 & $\begin{array}{c}10 \%\left(70^{\circ} \mathrm{C}\right. \\
10 \mathrm{~min})\end{array}$ & 5 & $5.0-7.0$ & $\begin{array}{c}22000 \\
\text { nKat/mg }\end{array}$ & $\begin{array}{c}\text { Ullah and } \\
\text { Sethumadha } \\
\text { van }\end{array}$ & 2003 \\
\hline Peniophoralycii & $\begin{array}{l}\text { Aspergillus } \\
\text { oryzae }\end{array}$ & 58 & $\begin{array}{c}10 \%\left(70^{\circ}\right. \\
15 \mathrm{seg})\end{array}$ & 5.5 & $4.0-7.0$ & $\begin{array}{c}22,89 \\
\mathrm{nKat} / \mathrm{mg}\end{array}$ & $\begin{array}{c}\text { Ullah and } \\
\text { Sethumadha } \\
\text { van }\end{array}$ & 2003 \\
\hline Peniophoralycii & $\begin{array}{c}\text { Aspergillus } \\
\text { oryzae }\end{array}$ & $50-55$ & $\begin{array}{c}62 \%\left(80^{\circ} \mathrm{C}\right. \\
60 \mathrm{~min})\end{array}$ & $4.0-4.5$ & - & - & Lassen, et al. & 2001 \\
\hline $\begin{array}{c}\text { Agrocybepediade } \\
\mathrm{s}\end{array}$ & $\begin{array}{c}\text { Aspergillus } \\
\text { oryzae }\end{array}$ & 50 & $\begin{array}{c}47 \%\left(80^{\circ} \mathrm{C}\right. \\
60 \mathrm{~min})\end{array}$ & $5.0-6.0$ & - & - & Lassen, et al. & 2001 \\
\hline Ceriporia sp. & $\begin{array}{l}\text { Aspergillus } \\
\text { oryzae }\end{array}$ & $55-60$ & $\begin{array}{c}38 \%\left(80^{\circ} \mathrm{C}\right. \\
60 \mathrm{~min})\end{array}$ & $5.5-6.0$ & - & - & Lassen, et al. & 2001 \\
\hline Ceriporia sp. & $\begin{array}{l}\text { Aspergillus } \\
\text { oryzae }\end{array}$ & $40-45$ & $\begin{array}{c}22 \%\left(80^{\circ} \mathrm{C}\right. \\
60 \mathrm{~min})\end{array}$ & $5.0-6.0$ & - & - & Lassen, et al. & 2001 \\
\hline $\begin{array}{l}\text { Trametes } \\
\text { pubescens }\end{array}$ & $\begin{array}{c}\text { Aspergillus } \\
\text { oryzae }\end{array}$ & 50 & $\begin{array}{c}15 \%\left(80^{\circ} \mathrm{C}\right. \\
60 \mathrm{~min})\end{array}$ & $5.0-5.5$ & - & - & Lassen, et al. & 2001 \\
\hline $\begin{array}{c}\text { Aspergillus } \\
\text { awamori }\end{array}$ & $\begin{array}{l}\text { Aspergillus } \\
\text { awamori }\end{array}$ & 50 & $\begin{array}{c}20 \%\left(80^{\circ} \mathrm{C}\right. \\
5 \mathrm{~min})\end{array}$ & 3.0 and 5.5 & $2.5-6.5$ & $270 \mathrm{U} / \mathrm{mL}$ & Martin, et al. & 2006 \\
\hline $\begin{array}{l}\text { Aspergillus } \\
\text { fumigatus }\end{array}$ & $\begin{array}{l}\text { Aspergillus } \\
\text { awamori }\end{array}$ & 62 & $\begin{array}{c}15 \%\left(80^{\circ} \mathrm{C}\right. \\
5 \mathrm{~min})\end{array}$ & 3.0 and 5.5 & $2.0-7.5$ & $90 \mathrm{U} / \mathrm{mL}$ & Martin, et al. & 2006 \\
\hline $\begin{array}{c}\text { Aspergillus } \\
\text { awamori }\end{array}$ & $\begin{array}{l}\text { Aspergillus } \\
\text { awamori }\end{array}$ & - & - & 5 & $3.0-5.0$ & $\begin{array}{c}200 \\
(\mathrm{PU}) / \mathrm{mL}\end{array}$ & Martin, et al. & 2003 \\
\hline $\begin{array}{l}\text { Aspergillus } \\
\text { terreus CBS }\end{array}$ & $\begin{array}{c}\text { Hansenula } \\
\text { polymorph } \\
\text { a } \\
\end{array}$ & - & - & - & - & - & Wyss, et al. & 1999 \\
\hline $\begin{array}{l}\text { Aspergillus } \\
\text { fumigatus }\end{array}$ & $\begin{array}{c}\text { Hansenula } \\
\text { polymorph } \\
\text { a } \\
\end{array}$ & 55 & $\begin{array}{c}25 \%\left(60^{\circ} \mathrm{C}\right. \\
20 \mathrm{~min})\end{array}$ & - & - & - & Wyss, et al. & 1999 \\
\hline $\begin{array}{l}\text { Talaromyces } \\
\text { thermophilus }\end{array}$ & $\begin{array}{c}\text { Hansenula } \\
\text { polymorph } \\
\text { a } \\
\end{array}$ & - & - & - & - & - & Wyss, et al. & 1999 \\
\hline $\begin{array}{l}\text { Penicillium } \\
\text { chrysogenum }\end{array}$ & $\begin{array}{l}\text { Penicillium } \\
\text { griseorose } \\
\text { um }\end{array}$ & 50 & $\begin{array}{c}70 \%\left(80^{\circ} \mathrm{C}\right. \\
10 \mathrm{~min})\end{array}$ & 5 & $3.0-8.0$ & $2.86 \mathrm{U} / \mu \mathrm{g}$ & Corrêa, et al. & 2015 \\
\hline $\begin{array}{c}\text { Penicillium } \\
\text { chrysogenumCCT } \\
1273\end{array}$ & $\begin{array}{l}\text { Penicillium } \\
\text { griseorose } \\
\text { umPG63 }\end{array}$ & 50 & $\begin{array}{c}65 \%\left(80^{\circ} \mathrm{C}\right. \\
10 \mathrm{~min})\end{array}$ & 2.0 and 5.0 & $3.0-8.0$ & $2.86 \mathrm{U} / \mu \mathrm{g}$ & Corrêa, et al. & 2015 \\
\hline $\begin{array}{c}\text { Aspergillus } \\
\text { nigerNII0812 }\end{array}$ & $\begin{array}{c}\text { Kluyverom } \\
\text { yces lactis }\end{array}$ & 55 & $\begin{array}{c}17 \%\left(100^{\circ} \mathrm{C}\right. \\
45 \mathrm{~min})\end{array}$ & 3.2 & $3.1-3.4$ & $50 \mathrm{U} / \mathrm{mL}$ & $\begin{array}{c}\text { Ushasree, et } \\
\text { al. }\end{array}$ & 2015 \\
\hline $\begin{array}{c}\text { Thermomyceslan } \\
\text { uginosus }\end{array}$ & $\begin{array}{c}\text { Fusarium } \\
\text { venenatum }\end{array}$ & 65 & $\begin{array}{c}76,7 \%\left(69^{\circ} \mathrm{C}\right. \\
20 \mathrm{~min})\end{array}$ & 6 & $3.0-7.5$ & $91 \mathrm{U} / \mathrm{mg}$ & Berka, et al. & 1991 \\
\hline $\begin{array}{c}\text { Aspergillus } \\
\text { nidulans }\end{array}$ & $\begin{array}{c}\text { Nicotiana } \\
\text { benthamia }\end{array}$ & 55 & $\begin{array}{c}30 \%\left(75^{\circ} \mathrm{C}\right. \\
20 \mathrm{~min}) \\
\end{array}$ & 4.5 and 5.5 & $3.5-6.0$ & $176.4 \mathrm{U} / \mathrm{mL}$ & Oh, et al. & 2014 \\
\hline
\end{tabular}




\section{Open Access Journal of Microbiology \& Biotechnology}

\begin{tabular}{|c|c|c|c|c|c|c|c|c|}
\hline & na & & & & & & & \\
\hline Aspergillus niger & $\begin{array}{l}\text { Nicotiana } \\
\text { tabacum }\end{array}$ & - & - & - & - & - & George, et al. & 2005 \\
\hline $\begin{array}{c}\text { Aspergillus } \\
\text { ficuum }\end{array}$ & $\begin{array}{l}\text { Nicotiana } \\
\text { tabacum }\end{array}$ & 58 & $\begin{array}{c}20 \%\left(80^{\circ} \mathrm{C}\right. \\
20 \mathrm{~min})\end{array}$ & 2.0 and 4.0 & $1.5-5.0$ & $\begin{array}{c}420 \\
\text { nKat/ml }\end{array}$ & Ullah, et al. & 1999 \\
\hline $\begin{array}{c}\text { Aspergillus } \\
\text { japonicus }\end{array}$ & $\begin{array}{l}\text { Triticum } \\
\text { aestivum }\end{array}$ & - & - & - & - & - & Abid, et al. & 2017 \\
\hline Aspergillus niger & $\begin{array}{l}\text { Chlamydo } \\
\text { monas } \\
\text { reinhardtii }\end{array}$ & 37 & - & 3.5 & - & $5 \mathrm{U} / \mathrm{g}$ & Erpel, et al. & 2016 \\
\hline Aspergillus niger & $\begin{array}{c}\text { Maize } \\
\text { mature }\end{array}$ & - & - & - & - & - & Rao, et al. & 2016 \\
\hline $\begin{array}{l}\text { Aspergillus niger } \\
\text { NRRL3135 }\end{array}$ & $\begin{array}{c}\text { Brassica } \\
\text { napus }\end{array}$ & - & - & - & - & - & Peng, et al. & 2006 \\
\hline $\begin{array}{c}\text { Aspergillus } \\
\text { phytase }\end{array}$ & Zea mays L & - & - & - & - & $3115 \mathrm{U} / \mathrm{kg}$ & $\begin{array}{c}\text { Drakakaki, et } \\
\text { al. }\end{array}$ & 2005 \\
\hline $\begin{array}{c}\text { Aspergillus } \\
\text { ficuum }\end{array}$ & $\begin{array}{c}\text { Medicago } \\
\text { sativa } \\
\end{array}$ & 58 & $50 \%\left(63^{\circ} \mathrm{C}\right)$ & 3.0 and 5.5 & $2.5-6.0$ & 389.3 nKat & Ullah, et al. & 2002 \\
\hline Aspergillus niger & $\begin{array}{l}\text { Bombyxmo } \\
\text { ri body }\end{array}$ & 55 & $\begin{array}{c}84 \%\left(90^{\circ} \mathrm{C}\right. \\
30 \mathrm{~min}) \\
\end{array}$ & 1.5 & $1.5-2.0$ & $99.05 \mathrm{U} / \mathrm{g}$ & $\mathrm{Xu}$, et al. & 2014 \\
\hline Aspergillus niger & $\begin{array}{l}\text { Bombyxmo } \\
\text { ri pupa }\end{array}$ & 37 & $\begin{array}{c}84 \%\left(90^{\circ} \mathrm{C}\right. \\
30 \mathrm{~min})\end{array}$ & 5.7 & $5.5-6.0$ & $54.80 \mathrm{U} / \mathrm{g}$ & $\mathrm{Xu}$, et al. & 2014 \\
\hline
\end{tabular}

Table 1: Fungal phytases expressed in different hosts and their biochemical properties.

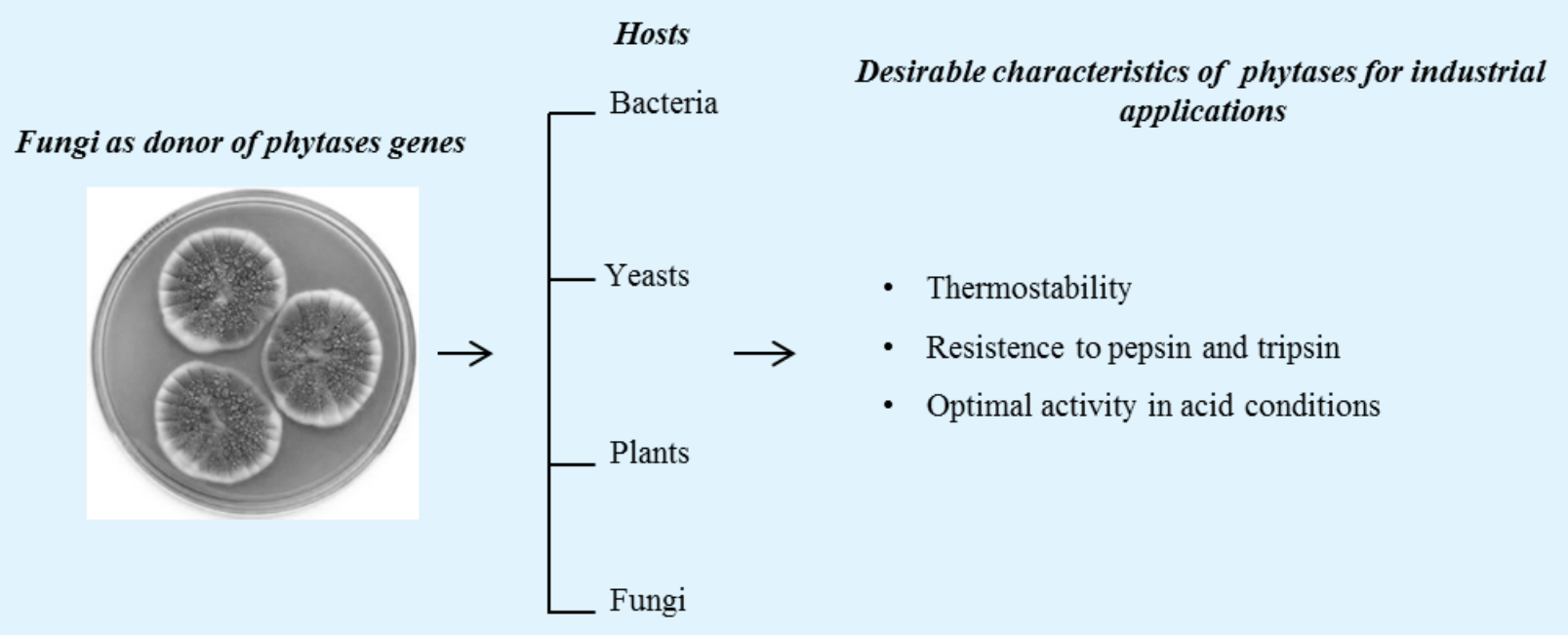

Figure 1: The graph representation of the main hosts used for fungal phytases production and its important biochemical properties for the developing of new phytases for industrial applications. The Penicillium picture was taken from web site https://lovecraftianscience.wordpress.com/tag/penicillium/.

\section{Bioreactors}

\section{Bacteria}

Since Escherichia coli is often used for heterologous expression researchers have dedicated efforts to produce fungal phytase in E. coli in soluble form. This strategy is highly desirable once it can help in high throughput screening of gene libraries constructed by directed evolution. Ushasree, et al. (2014) [1] performed the gene cloning and soluble expression of an Aspergillus niger NII 08121 phytase in E. coli in cytosol via co-expression of chaperones GroES/EL for improving cytosolic solubility of enzymes. This strategy could result in soluble and functional protein products. Alteration in its $\mathrm{pH}$ profile indicated the role of glycosylation conserving its characteristic properties [2-5] studying a histidine acid 


\section{Open Access Journal of Microbiology \& Biotechnology}

phosphatase (HAP) family phytases (rPhyXT52) from a southern pine beetle fungus garden showed (Dendroctonus frontalis) high enzymatic activity when be expressed in E.coli. Biochemical characterization has shown that phytase is tolerant to high temperatures. When compared to the disulfide bonds, the noncovalent interaction of the salt bridges might play more important roles in the heat-resilient property of these enzymes. The optimum pH (3.9) of the PhyXT52 is close to the usual gastric $\mathrm{pH}$ condition of livestock and poultry. E. colias host cells have advantages of easy cloning, maintenance and the formation of inclusion bodies can be bypassed with the co-expressed chaperones. However, the absence of glycosylation remains a disadvantage of the system.

\section{Yeasts}

The yeasts Pichiapastoris and Saccharomyces cerevisiae have was an interesting alternative as unicellular host cells due to their coatings glycosylated proteins in different patterns. $P$. pastoris has been used as a system of expression by several researchers Han and Lei (1999), Shi, et al. (2009), Wang, et al. (2007), Zhao DM, et al. (2007) Ullah, et al. (2000), Maldonado, et al. (2014) and Xiong, et al. (2006) [6-12]. They verified the expression of phytase from Aspergillus niger, A. fumigatus, $A$. japonicas and, Peniophoralycii. The results show that $A$. niger, A. fumigatus, A. japonicas phytases showed an improvement in their thermostability directly related to glycosylation. This enzyme showed a reduction in molecular mass, thermostability, enzymatic activity and alteration in the optimum $\mathrm{pH}$ when was deglycosylated. In contrast, phytase of $P$. lycii expressed showed no gain in its thermostability even having 10 potential glycosylation sites. The yeast $S$. cerevisia has been used as an expression system by several researchers worldwide Yanming, et al. (1999) and Wyss, et al. (1999) [13,14]. They verified the phytase expression of A. niger, $A$. fumigatus and Aspergillus terreus. Wyss, et al. (1999) [14] reported a phytase expressed in S. cerevisia that exhibited excessive glycosylation patterns. However, this excess of glycosylation did not affected the specific activity of the enzyme, the thermostability or the native folding. In another work the A. niger phytase showed a high thermostability when compared to the previous ones due to the high glycosylation range. In this way it is observed that the glycosylation pattern of P. pastoris has improved the thermostability of most of the phytases expressed when compared to phytases expressed in S. cerevisiae.

\section{Fungi}

The expression system in filamentous fungi has the advantage of high enzymatic production and the various post-transcriptional modifications, but as a disadvantage it has a variable pattern of glycosylation. The fungi A. niger and A. oryzae have been a profitable alternative capable of producing thermostable proteins due to their post-transcriptional machinery. The fungi A. niger expression system has been used expression by several researchers [14-18]. They have verified the expression of phytases from A. ficuum, A. terreus, A. fumigatus, Emericella nidulans, Myceliophthora thermophile and, A. niger. The results showed that the glycosylation patterns were highly variable, differing individually. A high thermostability was reported, for a A. fumigatus phytase, maintaining $90 \%$ of enzymatic activity at $100^{\circ} \mathrm{C}$ for 20 minutes. A. oryzae also has been used as a good expression system by some researchers Uchida, et al. (2006), Ullah and Sethumadhavan (2003) and Lassen, et al. (2001) [19-21]. They checked the phytase expression of A. oryzae, P. lycii, Agrocybe pediades, Ceriporia sp. and Trametes pubescens. The results showed phytases with high thermostability and restricted $\mathrm{pH}$ range (4.0-7.0). An important finding was reported by Lassen, et al. (2001) [21-23], basidomycete phytases has preference for attack on phytic acid 6-phosphate, a characteristic never observed in fungi.

Fungi such as A. awamori, H. polymorpha, Penicillium griseoroseum, Kluyveromyces lactis and Fusarium venenatum were used as an expression system others researchers Martin, et al. (2006), Martin, et al. (2003), Wyss, et al. (1999), Corrêa, et al. (2015), Ushasree, et al. (2015), Berka, et al. (1991) [24-29]. They have verified the expression from phytases of A. awamori, A. fumigatus, A. terreus, Talaromyces thermophilus, $P$. chrysogenum, $A$. niger, and Thermomyces lanuginosus. Based on this work the homologous expression of a P. chrysogenum phytase expressed in P. griseoroseum, highly stable phytase at room temperature for months.

\section{Plants}

The genus Nicotianahas been studied as an expression system by several researchers Ullah, et al. (1999), George et al. (2005) and Oh et al. (2014) [10,30,31]. They verified the expression of phytase enzymes from $A$. ficuum, $A$. niger and $A$. nidulans. The results have shown the possibility of overexpressing the phyA gene from Aspergillus in other commercial crop plants as an alternative for production of these enzymes [20]. Cloned and expressed the phyA gene in Medicago sativa (alfalfa) leaves. The kinetic parameters of the phyA gene gave nearly identical values to those of the native phytase. Phillippy and Mullaney (1997) [32] verified that phyA gene from when expressed in E. coli was shown to be stored in inclusion bodies and lacked activity. Attempts 
were made to refold the protein with concomitant regeneration of the activity but without success. This could be due to the lack of glycosylation of fungal phytase after expression in E. coli. Which can be bypassed by the expression system in glycosylating plants. Other types of plants have also been addressed for the expression of heterologous phytase. Plants such as Triticum aestivum, Chlamydomonas reinhardtii, Mature maize, Brassica napus and Zea mays $L$ were used to express A.japonicas phytases reported by Abid, et al. (2017) and A. niger studied by Rao, et al. (2016), Rao J, et al. (2013), Peng, et al. (2006) and Drakakaki, et al. (2005) [33-37] respectively.

\section{Other organism: Silkworm and Microalgae}

The use of silk worms is an attractive technological alternative for protein expression, once that the pupae are bioreactors of silk production. $\mathrm{Xu}$, et al. (2014) [38] demonstrated the use of transgenic silk worms, Bombyxmori, which was transformed with a codonoptimized A. niger phytase gene (phyA) under the control of the Bmlp3 promoter. The result of this work suggested this system as a potential, "bioreactors" for phyA expression with biomass being produced with low-costs. Microalgae also have high nutritional value. Erpel, et al. (2016) [39] developed a transgenic microalgae (Chlamydomonas reinhardtii) expressing an improved version of the PhyA gene of $A$. niger, to be used as a food supplement for monogastric animals. This research also tackled the nutritional problems regarding phosphorus deficiency and general animal nutrition.

\section{Mutagenesis Tools}

Phytase-directed mutagenesis of $A$. niger increased the specific activity of phytases in the $\mathrm{pH}$ 4-5 changing glutamic acid (E) by lysine (K) at position 300 (K300E) [40]. Also was reported an improvement in their thermostability through the changes T314S, Q315R, V62N clone P9 and S205N, S206A, T151A, T314S, Q315R clone P12 [11]. Changes in the amino acids Q53R and K91D caused an increasing of the enzymatic activity at pH 5.0 and a high affinity to substrate [41]. Changes in the amino acids P212H S238D T255E G377T and D461N caused a change in the interaction of amino acids H82 and Asp362 from the catalytic site, favorably altering the profile of the optimum $\mathrm{pH}$. Conversely, this changes affected negatively the thermostability of the enzyme [28]. Random mutagenesis by error-prone PCR (ep-PCR) in A. niger phytase increased the catalytic efficiency and reduced its thermostability, when the amino acids changes E156G, Q396RT236A and Q396 were made [42]. The site directed mutagenesis of $\mathrm{I} 44 \mathrm{E}$ and $\mathrm{T} 252 \mathrm{R}$ improved the thermostability and enzyme activity [43]. Random changes in phytase of Penicillium sp. in different clones (T11A, G56E, L65F, Q144H and L151S) and (T11A, H37Y, G56E, L65F, Q144H, L151S and N354D) resulted in an gain of enzyme regarding to thermostability and resistance to pepsin [44], The authors believe that new hydrogen bonds, improved the interaction of the secondary protein structures, reinforcing a possible explanation on protein thermal stability. Hybridization of $A$. terreus phytase with $A$. niger showed an increase of phytase thermostability when compared to wild type [16].

\section{Conclusion and Perspective}

The present review article showed several fungi phytases produced in different hosts as biofactories. In addition, this work has shown the main biochemical properties which are performed in order to obtain innovative products and thus, generate new phytases. One successful strategy is the site directed mutagenesis described previously. Finally, we hope that this article based on fugal phytases can expand our knowledge on recombinant fungal phytases expressed in different hosts

\section{Acknowledgements}

This work was supported by Fundação de Amparo à Pesquisa de Minas Gerais (FAPEMIG) Grant APQ-0083514, PRONEM/FAPEMIG. AS Galdino and NS Parachin thanks to Conselho Nacional de Desenvolvimento Científico e Tecnológico (CNPq) for its research fellowship.

\section{References}

1. Ushasree MV, Vidya J, Pandey A (2014) Gene cloning and soluble expression of Aspergillus niger phytase in E. coli cytosol via chaperone co-expression. Biotechnol Lett 36(1): 85-91.

2. Tan H, Wu X, Xie L, Huang Z, Peng W, et al. (2016) Identification and characterization of a mesophilic phytase highly resilient to high-temperatures from a fungus-garden associated metagenome. Appl Microbiol Biotechnol 100(5): 2225-2241.

3. Piddington CS, Houston CS, Paloheimo M, Cantrell M, Miettinen-Oinonen A, et al. (1993) The cloning and sequencing of the genes encoding phytase (phy) and $\mathrm{pH}$ 2.5-optimum acid phosphatase (aph) from Aspergillus niger var. awamori. Gene 133(1): 55-62.

4. Chen W, Yu H, Ye L (2016) Comparative Study on Different Expression Hosts for Alkaline Phytase 


\section{Open Access Journal of Microbiology \& Biotechnology}

Engineered in Escherichia coli. Appl Biochem Biotechnol 179(6): 997-1010.

5. Nassiri M, Ariannejad H (2015) Comparative Analysis of Peripheral Alkaline Phytase Protein Structures Expressed in E. coli. Rep Biochem Mol Biol 4(1): 1018.

6. Han Y, Lei XG (1999) Role of Glycosylation in the Functional Expression of an Aspergillus niger Phytase (phyA) in Pichiapastoris. Arch Biochem Biophys 364(1): 83-90.

7. Shi XW, Sun ML, Zhou B, Wang XY (2009) Identification, characterization, and over expression of a phytase with potential industrial interest. Can J Microbiol 55(5): 599-604.

8. Wang Y, Gao X, Su Q, Wu W, An L (2007) Cloning, expression, and enzyme characterization of an acid heat-stable phytase from Aspergillus fumigatus WY-2. Curr Microbiol 55(1): 65-70.

9. Zhao DM, Wang M, Mu XJ, Sun ML, Wang XY (2007) Screening, cloning and overexpression of Aspergillus niger phytase (phyA) in Pichiapastoris with favourable characteristics. Lett Appl Microbiol 45(5): 522-528.

10. Ullah AH, Sethumadhavan K, Lei XG, Mullaney EJ (2000) Biochemical Characterization of Cloned Aspergillus fumigatus Phytase (phyA). Biochem Biophys Res Commun 275(2): 279-285.

11. Hesampour A, Siadat SER, Malboobi MA, Mohandesi $\mathrm{N}$, Arab SS, et al. (2015) Enhancement of Thermostability and Kinetic Efficiency of Aspergillus niger PhyA Phytase by Site-Directed Mutagenesis. ApplBiocheBiotechnol 175(5): 2528-2541.

12. Peng RH, Yao QH, Xiong AS, Cheng ZM, Li Y (2006) Codon-modifications and an endoplasmic reticulumtargeting sequence additively enhance expression of an Aspergillus phytase gene in transgenic canola. Plant Cell Rep 25(2): 124-132.

13. Rodriguez E, Han Y, Lei XG (1999) Cloning, Sequencing, and Expression of an Escherichia coli Acid Phosphatase/Phytase Gene (appA2) Isolated from Pig Colon. Biochem Biophys Res Commun 257(1): 117-123.

14. Wyss M, Pasamontes L, Friedlein A, Rémy R, Tessier M, et al. (1999) Biophysical characterization of fungal phytases (myo-inositol hexakisphosphate phosphohydrolases): molecular size, glycosylation pattern, and engineering of proteolytic resistance. Appl Environ Microbiol 65(2): 359-366.

15. Ullah AHJ, Sethumadhavan K (2003) PhyA gene product of Aspergillus ficuum and Peniophoralycii produces dissimilar phytases. Biochemical and Biophysical Research Communications 303(2): 463468.

16. Jermutus L, Tessier H, Pasamontes L, van Loon AP, Lehmann M (2001) Structure-based chimeric enzymes as an alternative to directed enzyme evolution: phytase as a test case. J Biotechnol 85(1): 15-24.

17. Pasamontes L, Haiker $M$, Henriquez-Huecas $M$, Mitchell DB, van Loon APGM (1997A) Cloning of the phytases from Emericella nidulans and the thermophilic fungus Talaromyces thermophilus. Biochimicaet Biophysica Acta (BBA) - Gene Structure and Expression 1353(3): 217-223.

18. van Hartingsveldt $W$, van Zeijl CMJ, Harteveld GM, Gouka RJ, Suykerbuyk MEG, et al. (1993) Cloning, characterization and overexpression of the phytaseencoding gene (phyA) of Aspergillus niger. Gene 127(1): 87-94.

19. Uchida H, Sakamoto SAT, Kawasaki H (2006) Expression of Aspergillus oryzae phytase gene in Aspergillus oryzae RIB40 niaD(-). J Biosci and Bioeng 102(6): 564-567.

20. Ullah AH, Sethumadhavan K, Mullaney EJ, Ziegelhoffer T, Austin-Phillips S (2002) Cloned and Expressed Fungal phyA Gene in Alfalfa Produces a Stable Phytase. Biochem Biophys Res Commun 290(4): 1343-1348.

21. Lassen SF, Breinholt J, Østergaard PR, Brugger R, Bischoff A, et al. (2001) Expression, gene cloning, and characterization of five novel phytases from four basidiomycete fungi: Peniophoralycii, Agrocybepediades, a Ceriporia sp., and Trametes pubescens. Appl Environ Microbiol 67(10): 47014707.

22. Mullaney EJ, Daly CB , Kim T , Porres JM , Lei XG , et al. (2002) Site-directed mutagenesis of Aspergillus niger NRRL 3135 phytase at residue 300 to enhance catalysis at $\mathrm{pH}$ 4.0. Biochem Biophys Res Commun 297(4): 1016-1020. 


\section{Open Access Journal of Microbiology \& Biotechnology}

23. Lichtenberg J, Pedersen PB, Elvig-Joergensen SG, Skov LK, Olsen CL, et al. (2011) Toxicological studies on a novel phytase expressed from synthetic genes in Aspergillus oryzae. Regul Toxicol Pharmacol 60(3): 401-410.

24. Martin JA, Murphy RA, Potência RF (2005) Purification and physico-chemical characterisation of genetically modified phytases expressed in Aspergillus awamori. Bioresour Technol 97(14): 1703-1708.

25. Martin JA, Murphy RA, Power RFG (2003) Cloning and expression of fungal phytases in genetically modified strains of Aspergillus awamori. Journal of Industrial Microbiology and Biotechnology 30(9): 568-576.

26. Pasamontes L, Haiker M, Wyss M, Tessier M, Van Loon AP (1997) Gene cloning, purification, and characterization of a heat-stable phytase from the fungus Aspergillus fumigatus. Appl Environ Microbiol 63(5): 1696-7700.

27. Corrêa TLR, Queiroz MV, Araújo EF (2015) Cloning, recombinant expression and characterization of a new phytase from Penicillium chrysogenum. Microbiol Res 170: 205-212.

28. Ushasree MV, Vidya J, Pandey A (2015) Replacement $\mathrm{P} 212 \mathrm{H}$ altered the $\mathrm{pH}$-temperature profile of phytase from Aspergillus niger NII 08121. Appl Biochem Biotechnol 175(6): 3084-3092.

29. Berka RM, Rey MW, Brown KM, Byun T, Klotz AV (1998) Molecular characterization and expression of a phytase gene from the thermophilic fungus Thermomyces lanuginosus. Appl Environ Microbiol 64(11): 4423-4427.

30. George TS, Simpson RJ, Hadobas PA, Richardson AE (2005) Expression of a fungal phytase gene in Nicotiana tabacum improves phosphorus nutrition of plants grown in amended soils. Plant Biotechnol J 3(1): 129-140.

31. Oh TK, Oh S, Kim S, Park JS, Vinod N, et al. (2014) Expression of Aspergillus nidulans phy gene in Nicotiana benthamiana produces active phytase with broad specificities. Int J Mol Sci 15(9): 15571-15591.

32. Phillippy BQ, Mullaney EJ (1997) Expression of an Aspergillus niger Phytase (PhyA) in Escherichia coli. J Agric Food Chem 45(8): 3337-3334.
33. Abid N, Khatoon A, Maqbool A, Irfan M, Bashir A, et al. (2017) Transgenic expression of phytase in wheat endosperm increases bioavailability of iron and zinc in grains. Transgenic Res 26(1): 109-122.

34. Rao J, Yang L, Guo J, Quan S, Chen G, et al. (2016) Metabolic changes in transgenic maize mature seeds over-expressing the Aspergillusniger phyA2. Plant Cell Rep 35(2): 429-437.

35. Rao J, Yang L, Wang C, Zhang D, Shi J (2013) Digital gene expression analysis of mature seeds of transgenic maize overexpressing Aspergillus niger phyA2 and its non-transgenic counterpart. GM Crops Food 4(2): 98-108.

36. Xiong AS, Yao QH, Peng RH, Zhang Z, Xu F, et al. (2006) High level expression of a synthetic gene Encoding Peniophora Lycii Phytase in Methylotrophic Yeast Pichiapastoris. Appl Microbiol Biotechnol 72(5): 1039-1047.

37. Drakakaki G, Marcel S, Glahn RP, Lund EK, Pariagh S, et al. (2005) Endosperm-specific co-expression of recombinant soybean ferritin and Aspergillus phytase in maize results in significant increases in the levels of bioavailable iron. Plant Mol Biol 59(6): 869-880.

38. Liu Y, Wang F, Yuan L, Wang Y, et al. (2014) Overexpression and functional characterization of an Aspergillus niger phytase in the fat body of transgenic silkworm, Bombyxmori. Transgenic Res 23(4): 669677.

39. Erpel F, Restovic F, Arce Johnson P (2016) Development of phytase-expressing Chlamydomonas reinhardtii for monogastric animal nutrition. BMC Biotechnol 16: 29-36.

40. Mullaney EJ, Locovare H, Sethumadhavan K, Boone S, Gen Lei X, et al. (2010) Site-directed mutagenesis of disulfide bridges in Aspergillus niger NRRL 3135 phytase (PhyA), their expression in Pichiapastoris and catalytic characterization. Appl Microbiol Biotechnol 87(4): 1367-1372.

41. Tian YS, Peng RH, Xu J, Zhao W, Gao F, et al. (2011) Semi-rational site-directed mutagenesis of phyl $1 \mathrm{~s}$ from Aspergillus niger 113 at two residue to improve its phytase activity. Mol Biol Rep 38(2): 977-982.

42. Liao $\mathrm{Y}$, Zeng $\mathrm{M}, \mathrm{Wu} \mathrm{Z}$, Chen $\mathrm{H}$, Wang $\mathrm{H}$, et al. (2012) Improving Phytase Enzyme Activity in a Recombinant phyA Mutant Phytase from Aspergillus niger N25 by 
Error-Prone PCR. Appl Biochem Biotechnol 166(3): 549-562.

43. Liao Y, Li C, Chen H, Wu Q, Shan Z, et al. (2013) SiteDirected Mutagenesis Improves the Thermostability and Catalytic Efficiency of Aspergillus niger N25 Phytase Mutated by I44E and T252R. Applied Biochemistry and Biotechnology 171(4): 900-915.
44. Zhao Q, Liu H, Zhang Y, Zhang Y (2010) Engineering of protease-resistant phytase from Penicillium sp.: high thermal stability, low optimal temperature and $\mathrm{pH}$. J Biosci Bioeng 110(6): 638-645.

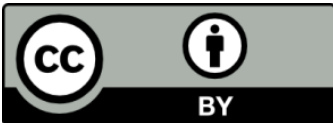

